\title{
HEAVY METAL RESIDUES IN HAIR SAMPLE OF RESIDENTS AROUND METAL RECYCLING FACTORIES IN IKORODU, LAGOS STATE, NIGERIA
}

\author{
${ }^{* 1}$ Sanyaolu, V. T., ${ }^{2}$ Eleyowo, O. O. and ${ }^{2}$ Ogundare, C. O. \\ ${ }^{1}$ Environmental Biology Unit, Department of Biological Science, School of Pure \& Applied Sciences, \\ Lagos State Polytechnic, Ikorodu. \\ ${ }^{2}$ Biochemistry Unit, Department of Chemical Science, School of Pure \& Applied Sciences, \\ Lagos State Polytechnic, Ikorodu. \\ *Corresponding author's email: vaksanyaolu@yahoo.com, vaksanyaolu2@gmail.com Tel: +234-808-741-2679
}

(Received: $13^{\text {th }}$ October, 2017; Accepted: $29^{\text {th }}$ August, 2018)

\section{ABSTRACT}

There is increasing global concern over the public health impacts attributed to heavy metal exposure. The analysis of human hair has been valuable in screening for such exposures. This research was conducted to determine residues of $\mathrm{Pb}, \mathrm{Cd}$ and $\mathrm{As}$ in hair samples of residents around scrap metal recycling factories in Odonguyan, Ikorodu, Lagos state. The study area was divided into three units P1, P2 and P3, each having an active recycling factory located $\leq 50$ metres to a populated area. Control samples were collected from a remotely located area (approximately $2 \mathrm{~km}$ ) from study area (P4). Samples were collected three times from 20 volunteers per location at 4 weeks interval. Volunteers were non-smoking adult males (18-35 years) with at least 7 years residency history in each sample area. Collected hair samples from each location were bulked, recut, thoroughly mixed and taken in 5 replicates for laboratory analysis. Sample preparation was conducted using standard procedures. Concentration of heavy metals in samples was determined using the Atomic Absorption Spectrophotometer (AAS; UNICAM 929 London). Data obtained were analysed using ANOVA. Mean separation was by LSD ( $\mathrm{p} \leq 0.01)$. Results showed that mean concentrations of $\mathrm{Pb}, \mathrm{Cd}$ and $\mathrm{As}$ were significantly higher ( $\mathrm{p} \geq 0.01)$ in all exposed groups compared to the control group. Mean concentration $(\mathrm{mg} / \mathrm{kg})$ ranges were:

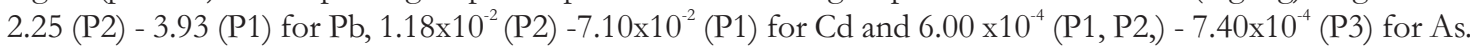
Mean values $(\mathrm{mg} / \mathrm{kg})$ for control group were $0.49,6.40 \times 10^{-3}$ and $2.00 \times 10^{-4}$ for $\mathrm{Pb}, \mathrm{Cd}$ and As respectively. All parameters were lower than maximum permissible limits for England, Italy and Japan except for Pb whose mean values were higher than safe limits for Japan in all study locations except the control. Thus, residents in the study area are exposed to toxic heavy metals resulting from poorly regulated activities of recycling industries.

Keywords: Heavy metals, Hair samples, Metal recycling factory, Residential area

\section{INTRODUCTION}

Rapid and unorganized industrialization and urbanization have contributed to the elevated levels of heavy metals in the urban environment in developing countries (Wong et al., 2003). Scrap metal recycling industries are among a number of industries that may contribute to the increasing amount of heavy metals in the environment (Sanyaolu and Adeniran, 2014). Many important metals have been recovered and recycled including iron and steel, copper, brass and aluminium (Norgate et al., 2007; Onwughara et al., 2010). However, improper recycling activities ranging from poor storage facilities to improper disposal of waste generated or accumulated during and after recycling activities can lead to heavy metal pollution of the environment. Heavy metal exposure occur significantly by occupational exposures as workers of the mining, production and processing of these metals have been so exposed (Ogwuegbu and Muhanga, 2005). Also, inhabitants around industrial sites are exposed through air by suspended particulate matters (USDOL, 2004; Ogwuegbu and Muhanga, 2005). Heavy metal enters into the body through ingestion and inhalation (Onwughara et al., 2010). Heavy metal residues have been reported in drinking water (Sanyaolu and Adeniran, 2014), cultivated soil and edible vegetables (Sanyaolu et al., 2011).

Some heavy metals are known to pose threat to humans on entering the body, as they become accumulated and impair various physiological functions, inducing multiple organ damage. Examples include Lead (Yedjou and Tchounwou, 2007), Cadmium (Tchounwou et al., 2001), Chromium (Tchounwou et al., 2001), Mercury (Sutton et al., 2002), Arsenic (Tchounwou et al., 2004). According to the United States 
Environmental Protection Agency (U.S. EPA), and the International Agency for Research on Cancer (IARC), these metals are also classified as either known or probable human carcinogens based on epidemiological and experimental studies (Tchounwou et al., 2012). Thus, their biological monitoring is essential for assessing damage to the body. Hair tissue analysis has been found to be an excellent tool for monitoring general health, nutritional status and toxic heavy metal exposure, for both animals and humans (Bhattacharya et al., 2004).

The use of human hair for monitoring heavy metals has been recommended by many researchers (Wenning, 2000; Seidel et al., 2001; Harkins and Susten, 2003; Pereira et al., 2004)

In general, the amount of element that is irreversibly incorporated into growing hair is proportional to the level of the element in other body tissues (Kaslow, 2011). Thus, loads of metals in hair correlate positively with body burden and with past or chronic ingestion of the elements (Kaslow, 2011). Clinical research indicates that hair levels of specific elements, particularly potentially toxic elements such as cadmium, mercury, lead and arsenic are highly positively correlated with pathological disorders in human (Jung et al., 2001). Quantitative analysis of lead in scalp hair has been explored as an aid in clinical diagnosis of chronic and acute lead poisoning (Chattopadhyay et al., 1977; Fergusson et al., 1981). The exposure level of lead and zinc in human scalp hair in occupationally exposed workers has been found to increase with the number of years an individual spent at the work place (KorantengAddo et al., 2010).

This study is aimed at assessing the lead, cadmium and arsenic burden in scalp hair of residents around metal recycling factories in Odonguyan, Ikorodu - Lagos, Nigeria. Odogunyan axis of Ikorodu appears to be a safe haven for poorly regulated metal recycling factories. Here, metal recycling factories are located within residential and commercial areas. Workers and residents in this area are exposed to fumes from metal recycling processes, which are released directly into the environment (Plate 1a). There is also the problem of exposed scrap metal heaps in dumpsites (Plate 1b) prone to releasing leachate into the environment, as well as direct effluent discharge into the environment (Plate 1c).

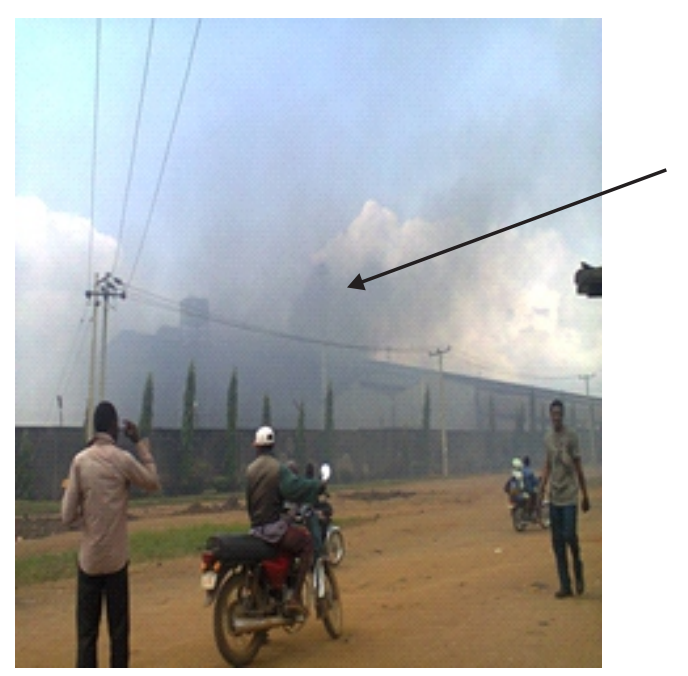

Plate 1a
Fumes from metal recycling processes released directly into the environment
Exposed scrap metal heaps in a recycling factory

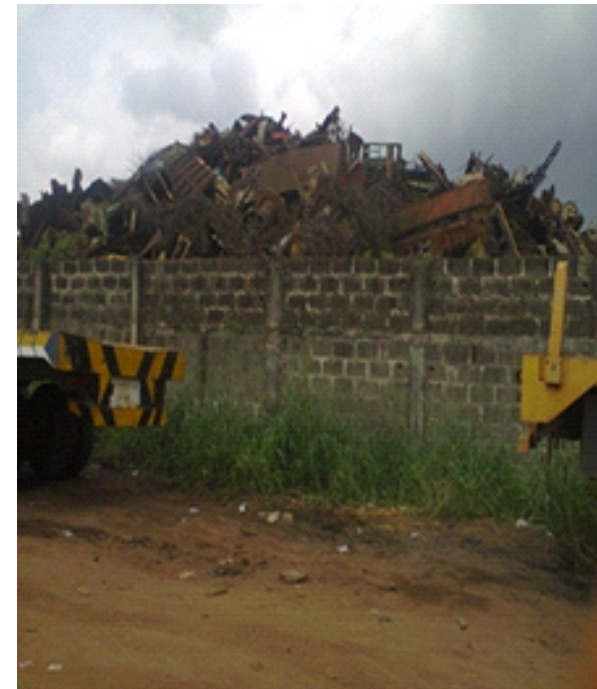

Plate $1 \mathrm{~b}$ 


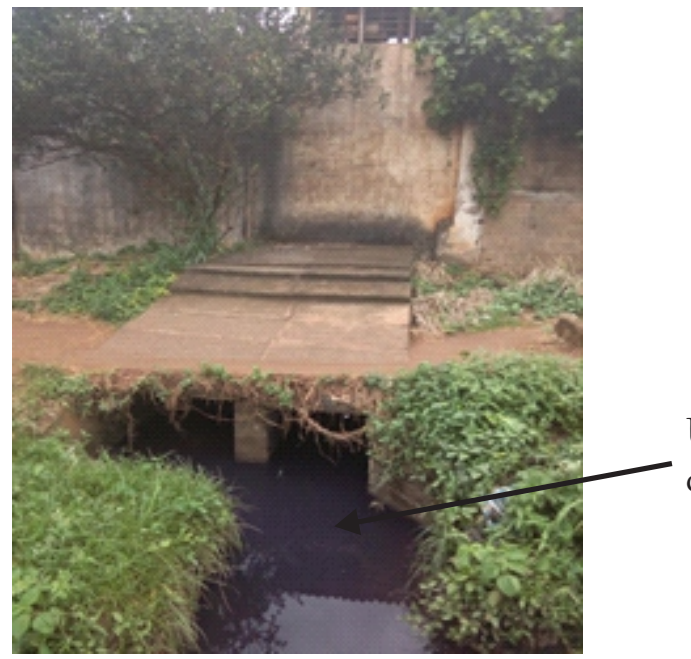

Plate 1c

\section{MATERIALS AND METHODS Site Description}

This work was carried out in Odonguyan area of Ikorodu, Lagos State. The sample area was subdivided into three units, each located at close proximity $(0-400$ meters $)$ to an operative scrap metal recycling factory. Each of the sample unit identified had a sample collection points denoted P1, P2 and P3 with coordinates N06 $68.083^{1}$,

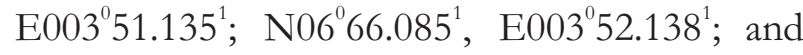
N06 $67.084^{1}, \mathrm{E} 003^{0} 51.136^{1}$ respectively. Control samples were also collected from volunteers who were students of Lagos State Polytechnic, Ikorodu Campus (P4) with coordinates N06 $24.015^{1}, \mathrm{E}$ $003^{0} 21.111^{\mathrm{I}}$ about 2,000 meters from Odonguyan.

\section{Collection of Samples}

Hair samples were collected from male volunteers between the ages of 18-35 years, who have stayed at least 7 years in this industrial area either as workers or as residents. The volunteers were those with undyed hair and with no smoking history to eliminate or reduce other probable routes of exposure to heavy metals. Volunteers were selected based on information obtained from questionnaires previously circulated. The control group was of similar criteria but comprised of people that have not resided in any industrial area. Samples were taken randomly from thirty (30) volunteers from each of the study units three times at 2 weeks interval between August and October, 2014. At the end of the sampling period, collected samples from each unit were bulked, recut into smaller pieces to achieve homogeneity and proper-mixing. Five samples were taken from each of the bulked samples and kept in plastic bags, labeled and taken to the laboratory for analysis

\section{Sample Preparation}

Collected hair samples were treated according to the procedure recommended by International Atomic Energy Agency (Eltayeb and Van Grieken, 1989). Hair samples were first washed in acetone, then three times in distilled water and then once again in acetone to remove external contaminants. These were dried in an oven at 110 ${ }^{\circ} \mathrm{C}$ for 1 hour and then ashed in muffle furnace. They were then placed in a desiccator pending digestion and analysis.

\section{Digestion of Hair Samples}

Exactly $0.2 \mathrm{~g}$ of the ashed sample was weighed into a pre-cleaned borosilicate $250 \mathrm{ml}$ capacity beaker. Then $30 \mathrm{ml}$ of digestion solvent (nitric acid) was added to the weighed sample. The sample with the digestion solvent was placed on the hot plate for digestion in the fume cupboard. After digestion, the beaker and its contents were allowed to cool. Another $20 \mathrm{ml}$ of the digestion solvent was added and digested further in the fume cupboard and the mixture was allowed to cool to room temperature. The mixture was filtered into a $250 \mathrm{ml}$ volumetric capacity borosilicate container. The filtrate was made up to the mark with de-ionized water. All the digested samples were sub sampled into pre-cleaned borosilicate glass containers for Atomic Absorption Spectrophotometer Analysis. 


\section{Analysis of Samples}

Standard solutions of arsenic, cadmium and lead solutions of $\quad 0.2,0.4,0.6,0.8$ and $1.0 \mathrm{mg} / \mathrm{L}$ were made from each respective metal solution of 1000 $\mathrm{mg} / \mathrm{L}$ stock solution of the analytes. The set of standard solutions and the filtrate of the digested samples were then analysed using the Atomic Absorption Spectrophotometer (AAS). The detection limit of the metals in the samples was $0.0001 \mathrm{mg} / \mathrm{L}$ by means of this model powered by SOLAAR software. Lead, cadmium and arsenic cathode lamps were used for the analysis of the respective heavy metal ions in the standards and filtrate of the samples. Gas mixtures were used in the generation of the flame.

\section{Analysis of Data}

Data collected were subjected to Analysis of Variance (ANOVA) using the complete randomized design (CRD). Mean separation was carried out using Least Significant Difference (LSD).

\section{RESULTS}

Results obtained from laboratory analysis of hair samples are presented in table 1. Results revealed that in all three heavy metals studied, the control group recorded the least concentration of metal in scalp hair. Details of results obtained are explained below:

\section{Lead $(\mathbf{P b})$}

Results obtained for mean lead concentration in the study groups were $3.93 \mathrm{mg} / \mathrm{kg}, 2.25 \mathrm{mg} / \mathrm{kg}$ $3.49 \mathrm{mg} / \mathrm{kg}$ and $0.49 \mathrm{mg} / \mathrm{kg}$ respectively for P1, $\mathrm{P} 2$ and P3 and P4 (control) (Table 1). There were significant differences $(\mathrm{p} \geq 0.01)$ between all the exposed groups and between the exposed groups and the control group. Significantly highest $(\mathrm{P} \geq$ 0.01) lead concentration (3.93 $\mathrm{mg} / \mathrm{kg})$ was observed at study unit P1.

\section{Cadmium (Cd)}

Highest mean cadmium $0.012 \mathrm{mg} / \mathrm{kg}\left(1.20 \times 10^{-2}\right.$ $\mathrm{mg} / \mathrm{kg}$ ) was observed among study unit P3 whereas the lowest mean value for same $\left(6.40 \times 10^{-3}\right.$ $\mathrm{mg} / \mathrm{kg}$ ) was among the control group. No significant difference $(\mathrm{P} \leq 0.01)$ was observed between the exposed groups, but a significant difference $(\mathrm{P} \geq 0.01)$ occurred between the exposed groups and the control group (Table1).

\section{Arsenic (As)}

The results show that mean arsenic concentration (mg/kg) for group 3 was significantly higher $(\mathrm{P} \geq$ 0.01) than those in $P 2$ and $P 3$ which showed no significant differences $(\mathrm{P} \leq 0.01)$ between them. However, mean As was significantly lower than in the control group compared to all three exposed groups.

Table1. Mean Concentration of Heavy Metals $(\mathrm{Mg} / \mathrm{Kg})$ in Hair Samples of Volunteers in Study Sites

\begin{tabular}{llll}
\hline \multirow{3}{*}{$\begin{array}{l}\text { Heavy metals }(\mathrm{mg} / \mathrm{kg}) \\
\text { points }\end{array}$} & Lead $(\mathrm{Pb})$ & Cadmium $(\mathrm{Cd})$ & Arsenic $(\mathrm{As})$ \\
\hline 1 & $3.93^{\mathrm{d}}$ & $0.0071^{\mathrm{b}}$ & $0.0006^{\mathrm{b}}$ \\
2 & $2.25^{\mathrm{b}}$ & $0.0118^{\mathrm{b}}$ & $0.0006^{\mathrm{b}}$ \\
3 & $3.49^{\mathrm{c}}$ & $0.0120^{\mathrm{b}}$ & $0.0074^{\mathrm{c}}$ \\
4 (control) & $0.49^{\mathrm{a}}$ & $0.0064^{\mathrm{a}}$ & $0.0002^{\mathrm{a}}$ \\
\hline
\end{tabular}

Mean values having same superscript along a column are not significantly different $(\mathrm{p} \leq 0.01)$ LSD 


\section{DISCUSSION}

Elevated levels of toxic heavy metal residues as observed in the exposed group in this study shows that scrap metal recycling factories contribute to the increasing amount of heavy metals in the environment. This agrees with earlier report by Sanyaolu and Adeniran (2014) who stated that this occurs as a direct consequence of improper and poorly regulated recycling activities of these factories. In the present study, higher levels of toxic heavy metals were observed among residents at close proximity to recycling metal factories. This agrees with earlier report that occupational exposures (Ogwuegbu and Muhanga, 2005) as well as residing at close proximity to metal recycling sites (USDOL, 2004; Ogwuegbu and Muhanga, 2005) are probable causes of exposure to toxic heavy metals. According to Vahter et al. (1991) and Kim and Fergusson (1993) uptake of heavy metals occurs through ingestion and inhalation, although percentage uptake is higher for inhaled metals than for ingested metals. Routes of exposure in the study area are probably through inhalation of contaminated smoke laden air usually common around the factories and also through intake of contaminated food and water.

Earlier reports had shown that hair levels of metals correlate positively with body burden, past or chronic ingestion of the elements and highly with pathological disorders (Jung et al., 2001). Higher levels of lead in the exposed group especially among study groups P1 and P3 therefore mean higher levels of this metal in the body of individuals in these study groups. Furthermore, Mean $\mathrm{Pb}$ concentration $(\mathrm{mg} / \mathrm{kg})$ in all three study units were above safe limit of 0.03 for Italy (Buchancova et al, 1993) and 1.4 for Japan (Turnland, 1988). This further suggests that population at this study units may suffer some health risk of lead toxicity. Low levels of lead in blood have been associated with increase blood pressure, decreased creatinine clearance, subtle decrements in cognitive performance and iron deficiency (ATSDR, 2000).

Accumulated lead in human is mostly sequestered in the bones and teeth and this leads to brittle bones and weakness in the wrists and fingers. This finally enters the blood stream during the periods of increased bone mineral recycling namely pregnancy, lactation, menopause, advancing age, etc (Todd, 1996). Mobilized lead can be redeposited in the soft tissues of the body and can cause musculoskeletal, renal, ocular, immunological, neurological, reproductive, and developmental effects (ATSDR, 1999). Kidney diseases including interstitial nephritis, tubular damage, hyperuricemia, decline in glomerular filtration rate, chronic renal failure have been observed in adults as a result of lead poison (Rubin, 1998).

Furthermore, higher levels of cadmium and arsenic in the exposed population compared to the control group suggest their pollution probably in lower concentrations in the study area. Moreover, mean concentrations of cadmium in scalp hair in all exposed groups were below permissible levels of 0.11 for England (IOSHIC, 1999); 0.03 for Italy (Buchancova et al, 1993), and 0.05 for Japan (Turnland, 1988)). Mean concentration of arsenic in all groups examined were also lower than the permissible limit of $0.02 \mathrm{mg} / \mathrm{kg}$ for England (IOSHIC, 1999) These values therefore indicate that there is no immediate risk to the exposed groups. However, these metals may become elevated in the future due to the chronic ingestion and bioaccumulation.

\section{CONCLUSION AND RECOMMENDATION}

Based on the result obtained from this study, it is obvious that workers and residents are exposed to toxic heavy metals due largely to indiscriminate and poorly regulated activities of recycling industries in the study area. This may be due to the fact that they are generally ignorant of potential danger posed by heavy metals to human and the environment. Hence, the following are recommended:

1. Relevant agencies should enlighten concerned population of the dangers of exposure to these pollutions.

2. Government should enforce strict compliance by industries to world standards for all recycling procedures.

\section{REFERENCES}

ATSDR, (Agency for Toxic Substances and Disease Registry). 2000. Toxicological Profile for Arsenic. US Department of Health and 
574 Sanyaolu et al.: Heavy Metal Residues in Hair Sample of Residents around Metal Recycling Factories

Human Services. Public Health Service, 205-1999-00024.

ATSDR, (Agency for Toxic Substances and Disease Registry), 1999. Toxicological Profile for Lead. US Department of Health and Human Services.Public Health Service, 205-93-0606.

Bhattacharya, M. Chatterjee, A., Kishore, R., Sudarsham M. and Chakraborty, A. 2004. Elemental concentration in hair of domestic animals-a SEM-EDS study. Ind. J. Vert. Anat.9: 61-68.

Buchancova, J., Vrlik, M., Knizkova, M., Mesco, D and Holko.L. 1993. Levels of selected

element (Fe, As, Cd, Pb, Zn, Mn) in biological samples from ferrochromium workers. BratislLek. Listy. 94: 373-387.

Chattopadhyay, A., T.M. Roberts and R.E. Jervis, 1977. Scalp hair as a monitor of community exposure to lead. Arch. Environ. Health, 32: 226-236.

Eltayeb, M.A.H., Van Grieken, R.E., 1989. Preconcentration and XRFdetermination of heavy metals. Journal of Radioanalytical and Nuclear Chemistry, 131 (2):331-342.

Fergusson, J.E., K.A. Hibbard and R.L.H. Ting, 1981. Lead in human hair: General surveybattery factory employees and their families. Environ. Pollut. Ser. B: Chem. Phys. 2: $235-248$.

Harkins, D. K. and Susten, A. S. 2003. Hair Analysis: Exploring State of Science. Environ Health Perspect, 111(4): 576 - 578.

International Occupation Safety and Health Information Centre (IOSHIC). 1999. Prevention Today, 5(3): 1-12

Jung, S. R. Yang, J. K. Han, G. H. Kang and G. H. Lee. 2001, "Determination of Lead, Cadmium, and Chromium in Hair Optimised by Simplex Method Using Electrothermal Vaporization-Inductively Coupled Plasma Mass Spectrometry," Analytical Sciences, 17:999-1002.

Kaslow, J. E. 2011. Hair Analysis: Cadmium Is Considered a Toxic Heavy Metal with No Known Metabolic Function in the Body. Physician and Surgeon Board Certified Internal Medicine, Santa Ana, 2011, p. 16.

Kim, N., and Fergusson, J. 1993.Concentrations and sources of Cadmium, Copper, Lead and Zinc in Dust in Christchurch, New Zealand. Science of the Total Environment, 138: 1-21.

Koranteng-Addo, J.E., E. Owusu-Ansah, L.K. Boamponsem, J.K. Koka and R.O. Agjei, 2010. Analyses of lead and zinc levels in human scalp hair in occupationally exposed workers in Cape Coast, Ghana. J. Chem. Pharm. Res. 2(5): 384-391.

Norgate, T.E., Jahanshahi, S. and Rankin, W. J. 2007. Assessing the environmental impact of metal production processes. Journal of Cleaner Production, 15: 838-848

Ogwuegbu M.O.C. and Muhanga W., 2005. Investigation of lead concentration in the blood of people in the copper belt province of Zambia. Journal of Environment, 1:66-75.

Onwughara N. I., Nnorom I. C., Kanno 0. C. and Chukwuma R. C. 2010. Disposal methods and heavy metals released from certain electrical and electronic equipment wastes in Nigeria: Adoption of environmental sound Recycling system. International Journal of Environmental Science and Development, 1(4):290-297

Pereira, R., Ribeir, R. and Goncalves, F. 2004. Scalp Hair Analysis as a Tool of Assessing Exposure to Heavy Metals (S. Domingos mine, Portugal). Science of the Total Environment, 327:81 - 92.

Rubin, A. 1998. Presentation on sludge and [the] 503 rule. Presentation before the $\mathrm{NH}$ Environment and Agriculture Committee, Nov 19

Sanyaolu, V.T., Sanyaolu, A.A.A. and Fadele, E. 2011. Spatial variation in Heavy Metal residue in Corchorus olitorius cultivated along a Major highway in Ikorodu- Lagos, Nigeria. J. Appl. Sci. Environ. Manage, 15(2): $283-287$.

Sanyaolu V.T. and Adeniran A.A. 2014. Determination of Heavy Metal Fallout on the Surrounding Flora and Aquifer: Case Study of A Scrap Metal Smelting Factory in Odogunyan Area, Ikorodu, LagosState, Nigeria. Int. Res. J. Environment Sci. 3(4): 93-100.

Seidel, S., Kreutzer, R., Smith, D., McNeel, S. and Gilliss, D. 2001. Assessment of Commercial Laboratories Performing 
Hair Mineral Analysis. JAMA, 285(1): 67 72.

Sutton, D., Tchounwou, P.B., Ninashvili, N., Shen, E. 2002. Mercury induces cytotoxicity, and transcriptionally activates stress genes in human liver carcinoma cells. Intl J Mol Sci. 3(9):965-984.

Tchounwou, P.B, Ishaque, A.B, Schneider, J. 2001.Cytotoxicity and transcriptional activation of stress genes in human liver carcinoma cells (HepG2) exposed to cadmium chloride. Mol Cell Biochem. 222(12):21-28.

Tchounwou, P.B., Centeno, J.A., Patlolla, A.K. 2004. Review Arsenic toxicity, mutagenesis, and carcinogenesis--a health risk assessment and management approach. Mol Cell Biochem., 255(1-2):4755.

Tchounwou, P. B., Yedjou, C. G., Patlolla, A. K., Sutton, D. J. 2012. Heavy Metals Toxicity and the Environment. EXS, 101: 133-164

Todd, G. C. 1996. Vegetables Grown in Mine Wastes. Environmental Toxicology and Chemistry, 19 (3): 600-607.

Turnland, J. R. 1988. Copper nutrition, Bioavailabilty and influence of dietary factors. Journal of American Dietetic Association, 1:303-308.
USDOL, (United States Department of Labour). 2004. Occupational Safety and Health administration (OSHA). Safety and Health Topics: Heavy metals. USDOL Publication, Washington D.C. (w w w. os ha.gov/S L - T C / metalsheavy/index.html)

Vahter, M., Berglund, M., Lind, B., Jorhem, L., Slorach, S., and Friberg, L. 1991. Personal monitoring of lead and cadmium exposure - a Swedish study with special reference to methodological aspects. Scandinavian Journal of Work, Environment and Health, 17: 65-74.

Wenning, R. 2000. Potential Problems with Interpretation of Hair Analysis Results. Ensic. Sci. Intl. 107: 5 - 12.

Wong C.S.C., Li, X.D., Zhang, G., Qi, S.H., and Peng, X.Z. 2003. Atmospheric depositions of heavy metals in the Pearl River Delta, China. Atmospheric Environment, 37: 767-776

Yedjou CG, Tchounwou PB. 2007. N-acetyl-1cysteine affords protection against leadinduce cytotoxicity and oxidative stress in human liver carcinoma (HepG2) cells. Int J. Environ Res Public Health, 4(2):132-7. 